By FREDERICK C. HICKS

\title{
Professional Aspects of Law Librarianship
}

Dr. Hicks is professor of law and law librarian in the School of Law, Yale University.

W

ITHIN MY own experience I have seen public librarians as a class look askance at the professional standards of college and university librarians. They in turn have looked askance at special librarians and particularly at law librarians. To some extent each group was justified in its attitude of superiority. There was implicit in it, however, a fundamental error. We spoke glibly of professional development, as though all libraries should or could be poured into the same mold, to come out rounded into shape, and stamped with the hall mark of quality. There is of course a substantial substratum of technique and doctrine applicable to all libraries of whatsoever kind. We are all engaged in the same sort of work looking to the accomplishment of like ends. Where we differ is in the emphasis which we place in different kinds of libraries upon the various techniques used. This emphasis is determined by the purposes for which the respective libraries exist. We cannot evaluate the professional development of all kinds of libraries by standards set for a single dominant group, the public library, for example, because those standards were themselves chosen in response to special needs. We must ask, for each group, these questions: (I) professional development for what purpose; (2) for the benefit of what clientele; (3) to make useful what kinds of material?

\section{What Is "Professional Development"?}

Failure to keep such questions in mind is one of the reasons why librarians are sometimes accused of fostering a kind of professionalism, the motto of which might be "Libraries for the Librarians," instead of "Libraries for the Readers." Too easily we fall into the error of making our card catalogs chiefly for our own use, adhering to the rule "let the reader fall where he may." Too easily also we adopt a professional attitude with regard to other types of libraries, which can stifle initiative within our own ranks. A larger number of general librarians know what a law library is like than was formerly the case, but still the number is small. It is significant that there was no course in law librarianship until the summer of 1937. It is significant not as an indication of the backwardness of law librarians, but as an evidence of the unpreparedness of library schools to give such training. Judged by the standards which I have mentioned, law librarians were not in fact, until a score of years ago, deficient in professional attainments.

I confess that after I became a law librarian, following seventeen years of experience in four other types of libraries, I was inclined to undervalue the profes- 
sional achievements of my new colleagues. They did not habitually talk the language of library schools, or of other types of libraries. When they did use the phraseology, they sometimes gave it a different meaning. They were diverse in education, training and experience. Judged by general library standards, they did not constitute a professional group. But it soon became apparent that there were other and better standards by which to judge them. Almost to a person, they were doing that which is the foundation of all successful librarianship: adapting library techniques selectively to the books and clientele to be used and served. They were applying library skills, so far as they were useful, to their own particular problems, and steadfastly resisting the urge to adopt such skills indiscriminately, even at the risk of being thought to be unprogressive.

\section{First Stage of Law Library Development}

Only in comparatively recent library time have law librarians paid much attention to card catalogs, to subject classification, and to notation schemes for any kind of book classification. Why was this so? It was not because they were wholly ignorant of the value of such devices in the libraries where they were used. It was because they already had substitutes for them which in the state of law library development at that time were serving very well. Their books were listed, they were arranged, and they were referred to by something like call numbers.

At the time of which I speak, law libraries, with a few notable exceptions, were small, and they were used almost exclusively by lawyers, judges, law students and professors for the purpose of reading technical law. Made up largely of sets of books-statutes, reports and periodicals - and of treatises usually called for by authors' names, no great problems of shelf arrangement presented themselves. There was an actual classification according to an easily understood scheme which tradition had established. Call numbers were not needed because custom had provided substitutes-the "citations" used by lawyers.

The latter got their citations from printed digests and subject indexes. This great system of reference had already been developed by lawyers, legal writers and law book publishers, and did not need to be invented by law librarians. Law, for lawyers, was more elaborately indexed by subject in printed form than was any other class of literature. The test of a good law librarian was whether he knew this elaborate system of reference. This meant that he could concentrate most of his effort on reference work-the important job of making the contents of the books in his library available to readers.

Since so many of his necessary tools were already in printed form, it was natural for him to want his library catalog also to be printed, and so most law libraries made printed books of their catalogs, keeping them up to date on cards only until a supplement could be printed.

I have said that the books were classified, that is, grouped by criteria of similarity. The printed indexes to the contents of sets were, and still are, arranged chiefly by subject. This made subject classification of the books themselves of secondary importance. The lawyer was accustomed to work according to a routinehe found his references, then got or called for the books to which his citations referred. The librarian was expected to arrange the books so that each individual volume could be found as quickly as pos- 
sible. This result, he had learned, could best be achieved when a "form" classification was used.

Thus the small law library for the exclusive use of lawyers had its own tight little professional system made up of (I) printed subject indexes, (2) printed lists of books kept up to date by card catalogs and printed supplements, and (3) shelf arrangement suitable for quickly finding individual books when they were called for by citations. The whole constituted a scheme for serving readers by bibliographical means which the latter understood and approved. For the kind of library which I have described, it represented a satisfactory stage of professional development. Moreover, this system still has merit for handling part of a modern law library's problems.

I look upon the above as an honorable chapter in the history of law library professional development, but I would be the last to say that it is sufficient today. New conditions demand that there be added other types of professional efficiency. Growth in size of individual libraries is of itself sufficient to call for new skills. But this growth has been brought about not merely by adding more law books. The scope of the libraries as to subject matter has been broadened in response to demands of readers. An interesting situation has developed in which lawyers are asking for non-legal and quasi-legal material, while laymen are asking law libraries for legal material. The latter have become law book conscious, while technically trained readers are finding the traditional law book inadequate for their professional needs. The first of these results may be attributed to steadily increasing activities of government agencies bringing law home to every citizen; the second is due largely to new methods of teaching and study in the law schools.

Thus, by the very standards which I have suggested for judging the degree of professional development in any library, the law librarian is forced to broaden his training in order to meet new needs. New kinds of books, and interest in aspects of law different from those disclosed by the printed subject indexes, call for more elaborate cataloging and classification, and widen the field of required reference work.

\section{Professional Organization of Law Li- brarians}

Development of the professional organization of law librarians has been in stages which parallel those of individual libraries. The formation in 1907 of the American Association of Law Libraries was in response to a demand for something different from what was then available to the members of the American Library Association. That association furnished some of the charter members of the new association, and some of them were not law librarians. These latter thought they saw in the technique and problems of law librarians something that might be of value to them in their general libraries. They were right in assuming that the bibliographical tools of the law are worth knowing about.

The first major enterprise of the American Association of Law Libraries was the preparation of a printed index, the Index to Legal Periodicals, now in its thirtythird volume. It does for legal periodicals in the English-speaking world what the Wilson indexes do for general periodicals in English. It is a subject index according to legal headings, following the general scheme of the American Digest System. 
Although it is primarily a lawyer's tool, the headings are, in a surprising number of instances, the same as those used in the Wilson indexes (see "The Modern Medusa," Law Library Journal, I4:7-14, Apr. I92I). It filled a gap in the lawyer's bibliographical equipment, since no provision had been made for continuing the Jones index which then ended with the year I 899 .

The second important enterprise was the publication of the proceedings of the annual conferences, a modest pamphlet which has now developed into the Law Library Journal, issued six times a year. In the early years of this periodical, one sees attempts to improve the morale of law librarians, make them conscious of common problems, and bind them together into a professional group. Fortunately for the future of the association, a high degree of success was attained. Without such a result, it would have been impossible to carry through the professional projects that had been initiated. Many important articles have appeared in the Journal on the technical processes peculiar to law libraries, but there has always been a preponderance of bibliographical material useful as check lists, and to improve reference service. Thus the publications of the association, and the nature of its discussions at conferences for many years conformed to the kind of professional equipment which I have described as characteristic of individual law libraries.

As times have changed, new emphases have come. Stirred by demands of readers for a different kind of service, stress has been placed on education for law librarianship. A standing committee, working with committees of other associations, has been active, and practical results have been achieved. In 1937, the Association of
American Law Schools adopted an article of association which requires that all member schools shall have "a qualified librarian, whose principal activities are devoted to the development and maintenance of an effective library service." The next step, now under consideration, is the implementing of this article by determining what qualifications such librarians must actually possess. A report is also being prepared on the functions of law library positions of all grades, and on the training and compensation that should be associated with the respective positions.

Another practical result, partly at least attributable to the efforts of the American Association of Law Libraries, is the institution of a course in law librarianship, given first in the summer of 1937 , by the Columbia University School of Library Service. A second course of one year's duration is announced for $1940-4 \mathrm{I}$, to be given cooperatively by the Law School and the School of Librarianship of the University of Washington.

Under recent presidents, the aims of the American Association of Law Libraries have been restated after prolonged discussion of a plan prepared by a committee under the chairmanship of William R. Roalfe, law librarian of the Duke University School of Law. The financial condition of the association has been improved (although this is a perennial problem), and a standing committee on planning has been set up. The whole tempo of the association has been quickened, and all of its members are conscious of the new requirements which new needs and conditions have placed upon them individually and as associates in a professional group.

\section{Experience in One Law Library}

I have been asked by the editor of $\mathrm{Col}$ - 
lege and Research Libraries to be specific in illustrating the trend of events in individual law libraries. I can do this best by describing briefly some of the developments during the last ten years in the library with which I am associated.

The ideal toward which we strive is indicated by guiding principles which are constantly reiterated to the staff, to the university administration, and to readers:

A library is a collection of books, properly housed, and organized for service.

It is our duty to anticipate the needs of our accredited clientele. Within the scope of the library, we are remiss if, when a book is called for, we lack it, or are unable to give satisfactory information concerning it.

The justification for library expenditures is the character as well as the extent of the use of its collections.

We aim to make the library notable for the completeness of its files, for nothing is so discouraging to scholarship as broken sets.

As many as possible of the more commonly used books should be on the open shelves in the reading room for consultation without formality. Stack service must be maintained at all times when the library is open.

The library must remain open as many hours as it will actively be used. [It is open during term time from 8 A.M. to I I P.M., seven days a week.]

The reader is entitled to every courtesy, and to all the skill that a trained staff can bring to the task of enabling him to do his own work. The administration and the staff must be imbued with the spirit of service, and this should show in the conduct of all from chief librarian to page.

\section{Staff and Organization}

In an endeavor to approach the ideal set by these principles, all persons added to the staff during the last ten years, to fill positions of professional grade, have been graduates both of colleges and library courses.

The evils of over-departmentalization have been avoided, so that the library may function as a unit. In any library there are four major undertakings, (I) general planning and oversight, (2) getting the books, (3) recording and preparing them for use by readers, and (4) conduct of a readers' service. These correspond to the four staff departments in this library:

I. General Administration. Policy, budget, recruiting the staff, salaries, payrolls, publicity, supplies, correspondence, statistics, approval of expenditures and bills.

2. Accessions Department. Orders, gifts, exchanges, handling of duplicates, checking bills, preparation of want lists and lists of duplicates.

3. Cataloging and Classification. This department has charge of all processes through which a book passes from the time it comes from the accessions department until it is ready for the shelves. This includes cataloging, classification, shelf-listing, dexigraphing, filing cards, marking, bookplating, mending, binding and rebinding. It is believed that these functions are so intimately connected that only delay and confusion result from dividing responsibility for them.

4. Readers' Service. Reading room, loan desk, bookstacks, reference work, service to professors in their offices.

\section{Cataloging}

In the last decade the library has more than doubled in size. The card catalog, however, has grown from 129 trays to 670 . This disproportionate growth in the cata$\log$ is partly due to the increase in the library itself, but chiefly to the facts that the scope of the library as to subject matter has been broadened, the whole library is in process of recataloging, and most important of all, the subjects treated in all books cataloged, legal as well as quasilegal, are more fully represented than formerly.

A guiding principle in our cataloging is that every book which is retained on the 
shelves shall be fully cataloged and provided with subject cards for both its legal and non-legal aspects. We do not use a special legal subject heading book, because of the danger of limiting the catalogers' mental horizon to such a list. On the contrary, we use the most comprehensive list available, viz., Subject Headings Used in the Dictionary Catalogues of the Library of Congress, adding to it such legal headings as are needed. We do not, of course, cease to rely on the printed subject indexes (digests, Index to Legal Periodicals, etc.) referred to above. To do so, duplicating their entries in our catalog, would show a wasteful lack of skill in using our legal tools, and would make the card catalog unnecessarily costly. But we do bring out in the card catalog many aspects of the books which the scheme of such printed indexes does not cover. By this means and by keeping constantly before us the potential usefulness of all phases of our books, we have, through the card catalog, immensely enriched the collection.

\section{Classification}

We would gladly have adopted a Library of Congress scheme of law book classification if that had been available, and we do use in modified form its JX schedules for international law. After waiting for many years for the Library of Congress to publish its $\mathrm{K}$ ( $\mathrm{Law}$ ) scheme, the present writer reluctantly decided to make one of his own for use in this library. It was published in September, 1939, with the title Yale Law Library Classification (Yale Law Library Publications, No. 8) after having been in use, while being developed, for nearly ten years. At the outset, fateful decisions had to be made:

Should it be primarily a subject classi- fication or should it be primarily a form classification? The latter was chosen, but with provision for some subject groups, and with the possibility of adding more.

Should we get up a complete scheme before we used any part of it? We decided to do it piecemeal, without regard to logical coherence in the scheme as a whole. We would not try to duplicate in our scheme for book arrangement, the subdivisions which lawyers have devised for the subject law. We would make a series of separate schedules for groups of books which, for whatever reason, we wanted to stand together.

The method of work is described as follows in the Introduction:

In deciding upon groups of books for which schedules were to be made, the reverse of the ordinary process was employed. A general policy [as mentioned above] was first adopted, but this was not followed by a vast scheme in which the relation of each group of books to all other groups was decided upon in advance. Although there are in fact three main divisions of the scheme (i.e. (1) special subject classes, (2) AngloAmerican law, and (3) foreign law), the groups that make up these theoretical divisions are not tied together by common symbols, nor are they shelved together unless it happens to be convenient to do so. Having made up a group of like books (like, according to the criteria of likeness which we adopted) which should stand together, a symbol-was adopted for that group, the method of indicating its subdivisions selected, and the scheme for constructing call numbers chosen. This process was repeated with other groups, one after the other, until the whole field had been covered.

A second section is made up of schedules for non-legal and quasi-legal books relating to history, philosophy, economics, sociology and political science, and a few other subjects. These schedules are simpler and less scientific than those used for 
such subjects in general libraries, but they are required in order that call numbers may be made, and so that such books may not be forced into unsuitable legal schedules. Their only justification -is that they serve a special purpose in this library.

Constructing classification schedules is no new experience for librarians, but there is a feature of the printed Yale Law Library Classification which is unusual. For each class, following the schedule, there is a subdivision on practice. Part of this deals with the method of applying the schedule, with directions for making call numbers, illustrated by examples. Another part deals with cataloging as applied to that class- the public catalog, the official catalog and the shelf list, author and other main entries, title and added entries, cross references, subject headings, forms for tabulated cards used for series and sets, and methods of cataloging and handling pamphlets and theses. Still another part deals with marking, stamping, bookplating and binding. Finally there are references to a few check lists and bibliographies useful in connection with the respective classes. This kind of material was added to the schedules because of the close relationship between cataloging, classification and preparation for the shelves, and because of the necessity for having in mind all phases of the work in relation to each class at one and the same time.

\section{Present and Future Problems}

Professional development in libraries has not reached its final stage. Particularly is this so in regard to the adaptation of skills to particular needs. It would be unfortunate if college and research libraries (including law libraries) adopted in toto the techniques which have been thought to be standard for other libraries. Librarians are usually not free agents. Even in the most prosperous of libraries, they are often forced to adopt substitutes for devices too costly for them to use. Perhaps some of these substitutes will turn out to be better than those which they replace. There is still opportunity to use initiative and imagination in library work. If anywhere the impact of problem on person can kindle a flame of invention, this flame should not be snuffed out by the imposition of set rules laid down by an authority which says, "This is the only way to do it."

The fact is that many problems heretofore thought to have been solved are again rearing their heads because of the growth of libraries. Mere bigness makes some techniques inapplicable. Free access to shelves is a fine idea, but it cannot be applied to all parts of our largest libraries because of the great cost of supervision. Connected with the idea of free access is that of subject classification. The larger a library is the less effective is such a grouping for the reader's shelf use. The classes themselves are richer in material, it is true, but at the same time, the amount of material on the same subject, which for good reasons is classed elsewhere, is largely increased. Subject classification could be applied to law libraries more extensively than is now customary, but would it be worth the cost? My point is that in no library can a subject arrangement bring together physically on the shelves all important material on a subject. I raise the question whether subject classification has not become a shibboleth by which to test excellence, erroneously leading us into costly excesses in library administration. Perhaps the conflict in most libraries is between close subject classification and 
broad subject classification, rather than between subject classification and form classification. Certain it is, however, that close subject classification is a costly and time-consuming undertaking, and that its refinements provide the motive for frequent reclassification.

Must we not recognize the supreme importance to libraries of the card catalog, especially on the subject side? It is the only place where any near approach to completeness of information concerning the resources of the library can be reached. Even here we leave out all those fields covered by printed subject indexes-the kinds which for a long time were the law library's chief subject catalogs, and which, thanks to Mr. Wilson, are of growing importance in every library.

If, for the sake of argument, this is agreed to, then there arises the question of whether or not we can improve our card catalogs. Can we simplify them from the reader's point of view? Are we sure that the so-called "dictionary" type is the best form? And, if it is, how can we make it more easily usable? Certainly it is a misnomer, in large catalogs, to say that the cards are arranged alphabetically as in a dictionary. In this process of im- provement and simplification, can we agree on a workable scheme for filing cards that we ourselves can understand without reference to the rule book? There is no agreement on so fundamental a thing as this, and the larger the catalog becomes, the more the user is confused. While I was writing these words, there came to my desk the Catalogers' and Classifiers' Yearbook, 1939. It contains articles with the following titles: "The Large Dictionary Catalog Faces Der Tag;" "Shall We Divide Our Catalog Vertically?;" "Crisis in the Catalog ;" "Horizontal Division of the Catalog ;" and, "The Public Catalog for Whom?" Another article begins with the question, "How far have we progressed since medieval days in the making of catalogs?" It ends with the warning, "Catalogers ... should beware falling into a rut from which they might be unable to climb out." All librarians, not catalogers alone, might well take this caution to heart.

And finally, what shall be done about the cost of cataloging? How can this mounting expense be reduced without destroying the effectiveness of the catalog? The answers to these questions are now of as much importance to law librarians as they are to any other kind. 